\title{
POTENSI LAHAN PERKEBUAN KELAPA SAWIT (Elaeis guineensis Jacq) DENGAN POLA TANAM TUMPANG SELA JAGUNG (Zea mays)
}

\author{
AFRIZAL \\ Jurusan Agri Bisnis Universitas Lancang Kuning Pekanbaru \\ Jalan Yos Sudarso KM. 08, Rumbai - Pekanbaru
}

\begin{abstract}
ABSTRAK
Penduduk Indonesia yang selalu bertambah di setiap tahunnya menyebabkan kebutuhan akan pangan meningkat. Pemenuhan kebutuhan pangan seperti jagung mengakibatkan peningkatan ketersediaan pangan. Usaha untuk mengatasi ketersediaan pangan dapat dilakukan dengan berbagai upaya seperti dengan intensifikasi lahan pertanian dan diversifikasi pangan.

Luas perkebunan di Riau sangat berpotensi untuk menanam tanaman pangan dengan sistem tumpang sela (intercroping) sewaktu tanaman pokok masih kecil atau belum produktif. Sistem tumpang sela (intercroping) dapat memaksimalkan lahan dibandingkan pola monokultur. Selain itu kegiatan tanaman tumpng sela (intercroping) dapat mensubsitusi pendapatan petani selama tanaman kelapa sawit belum menghasilkan (TBM). Artikel ini dibuat untuk mengetahui pengoptimalan lahan perkebunan untuk tanaman pangan jagung.
\end{abstract}

Kata Kunci : Potensi Lahan Perkebunan, Jagung, Kelapa Sawit 


\section{PENDAHULUAN}

Kelapa Sawit merupakan salah satu komoditas perkebunan yang penting dalam perekonomian Indonesia, baik sebagai penghasil devisa maupun penyedia lapangan kerja, sumber pendapatan utama petani, sumber pendorong pertumbuhan wilayah dan sumber pelestari lingkungan.

Produktivitas merupakan suatu hal yang sangat penting dalam usaha pertanian. Usaha untuk memenuhi kebutuhan ekonomi masyarakat baik hasil pertanian, jumlah, maupun kualitasnya harus ditingkatkan. Lahan untuk pertanian semakin terbatas karena alih fungsi lahan menjadi tempat pemukiman, industri, sarana jalan serta sarana fisik lainnya. Pada perkebunan rakyat produktivitas kelapa sawit adalah 5 ton TBS/ha/tahun, sedangkan pada Perkebunan Besar sudah mencapai >20 ton TBS /ha/tahun.

Salah satu upaya untuk meningkatkan produktivitas tanaman kelapa sawit Indonesia adalah melalui peremajaan. Upaya ini dinilai sebagai kegiatan yang sangat efektif untuk mendorong peningkatan produksi. teknologi peremajaan sawit dengan melakukan kegiatan tumpang sela (intercroping) tanaman jagung dapat menjamin kontinuitas pendapatan petani selama masa peremajaan.

Kualitas dan produktifitas tanaman jagung akan mempengaruhi pendapatan petani, semakin tinggi kualitas dan produktifitas jagung yang dihasilkan maka akan semakin tinggi pula pendapatan petani begitu pula sebaliknya semakin rendah kualitas dan produktifitas jagung semakin sedikit pula pendapatan bahkan sampe mengalami kerugian. 


\section{TINJAUAN PUSTAKA}

Jenis tanah di Riau didominasi oleh Podsolik Merah Kuning (PMK) yang dikenal mengandung sedikit unsur hara, sedikit mengandung bahan organik, dan $\mathrm{pH}$ yang rendah (Surtinah, 2012). Podsolik Merah Kuning (PMK) adalah Tanah Mineral telah berkembang, solum (kedalaman) dalam, tekstur lempung hingga berpasir, struktur gumpal, konsentrasi lekat, bersifat agak masam ( $\mathrm{pH}$ kurang dari 5,5), kesuburan rendah hingga sedang, warna merah hingga kuning, kejenuhan basa rendah, peka erosi. Tanah ini berasal dari batuan pasir kursa, tuv vulkanik, bersifat asam. Tersebar di daerah beriklim basah tanp bulan kering, curah hujn lebih dari $2500 \mathrm{~mm} /$ tahun (Surtinah, 2010).

(Hewayanti, et al., 2015) melaporkan bahwa pupuk hayati yang mengandung beberapa mikroorganisme yang berperan dalam menyediakan Nitrogen dan Fosfor seperti Azotobacter dan Bacillus sp yang terdapat di dalam Bio Extrim akan melaksanakan fungsinya dalam menyedikan unsur hara dalam meningkatkan berat tongkol jagung manis.

Hasil-hasil penelitian menunjukan bahwa pemberian bahan organik, terutama pada tanah-tanah bereaksi masam dan miskin unsur hara dapat meningkatkan kesuburan tanah melalui peningkatan $\mathrm{pH}$ tanah, menambah kapasitas tanah menahan air, perbaikan agregasi tanah, menambah kapasitas tukar kation tanah, dan pada gilirannya menambah unsur hara yang tersedia yang dapat diserap tanaman (Noyohadiprawiro dalam Herman, M dan Pranowo D.)

Kandungan gula pada jagung manis akan sangat menentukan kualitasnya. Kualitas hasil diukur dalam bentuk kandungan gula. Semakin tinggi kandungan gula maka kualitasnya semakin baik. Sukrosa dan gula reduksi ( glukosa dan fruktosa ) hasil fotosintesis yang ditransfer ke berbagai organ pengguna yang kemudian sebagian digunakan untuk pemeliharaan integritas organ tersebut, sebagian lagi dikonversi ke bahan struktur tanaman dan sisanya sebagai cadangan makanan (Harini 1993 dalam Surtinah, 2008). Jagung manis yang dipanen pada waktu yang tidak tepat akan berpengaruh terhadap kadar gula biji. (Surtinah, 2008) melaporkan bahwa umur panen 70 hari setelah tanam menunjukkan kadar gula biji jagung manis yang paling tinggi yaitu $15.78 \%$ untuk varietas sweet Boy. 


\section{HASIL DAN PEMBAHASAN}

Luas Perkebunan sawit di Riau sangat luas namaun pada perkebunan rakyat produktivitasnya sangat kurang yang disebabkan oleh beberapa faktor, salah satu faktornya adalah tanaman yang sudah tua. Tanaman yang sudah tua perlu dilakukan peremajaan untuk menambah produktivitas di masa yang akan datang.

Penanaman jagung pada tanah Podsolik Merah Kuning (PMK) dapat di atasi dengan menggunakan Bio Extrim, penggunaan Bio Extrim ini berfungsi sebagai menyedikan unsur hara dalam meningkatkan berat tongkol jagung manis.

Kualitas jagung manis ditentukan oleh kandungan gula yang terdapat didalamnya, pada penelitian diatas menunjukkan kadar gula biji jagung manis yang paling tinggi yaitu $15.78 \%$ untuk varietas sweet Boy yang di panen pada umur 70 hari setelah tanam .

Dengan pengolahan tanah perkebunan kelapa sawit yang baik untuk tanaman jagung dan pemberian pupuk yang sesuai serta penggunaan varietas jagung yang baik akan menghasilkan produksi yang optimal yang berimbas kepada pendapatan pertani, serta kelestarian tanah terjaga. 


\section{DAFTAR PUSTAKA}

Harini 1993 dalam Surtinah Umur Panen yang Tepat Menentukan Kandungan Gula Biji Jagung Manis (zea mays saccharata strut) [Jurnal] // Jurnal Ilmiah Pertanaian. - 2008. - Vol. 4 (2). - hal. 1-6.

Hewayanti E, Gofar N dan U H M Peningkatan Pertumbuhan Produksi Jagung Manis Melalui Penerapan Beberapa Jarak Tanam dan Pupuk Hayati di Lahan Lebak [Jurnal]. - Palembang : Prosending Seminar Golden Harvest, 2015. - Vol. 8(2). - hal. 1-6.

Noyohadiprawiro dalam Herman, M dan Pranowo D. Jagung Sebgai Tanaman Sela Pada Peremajaan Sawit Rakyat di Bagan Sapta Permai Riau [Jurnal]. - Sukabumi : Balai Penelitian Rempah dan Aneka Tanaman Industri.

Surtinah Agronomi Tanaman Budidaya [Buku]. - Pekanbaru : Alaf Riau, 2010. - hal. 73.

Surtinah dan Lidar, S. Pertumbuhan Vegetatif dan Kadar Gula Biji Jagung Manis (Zea mays saccharata, Sturt) di Pekanbaru [Jurnal] // J.IImiah Pertanian. - Pekanbaru : [s.n.], 2012. - Vol. 13(2). hal. 73-78.

Surtinah Menentukan Umur Panen yang Tepat dengan Menguji Kadar Gula Jagung Manis [Jurnal] // Jurnal Ilmu Pertanian. - 2008. - Vol. 4(2). - hal. 15-21. 